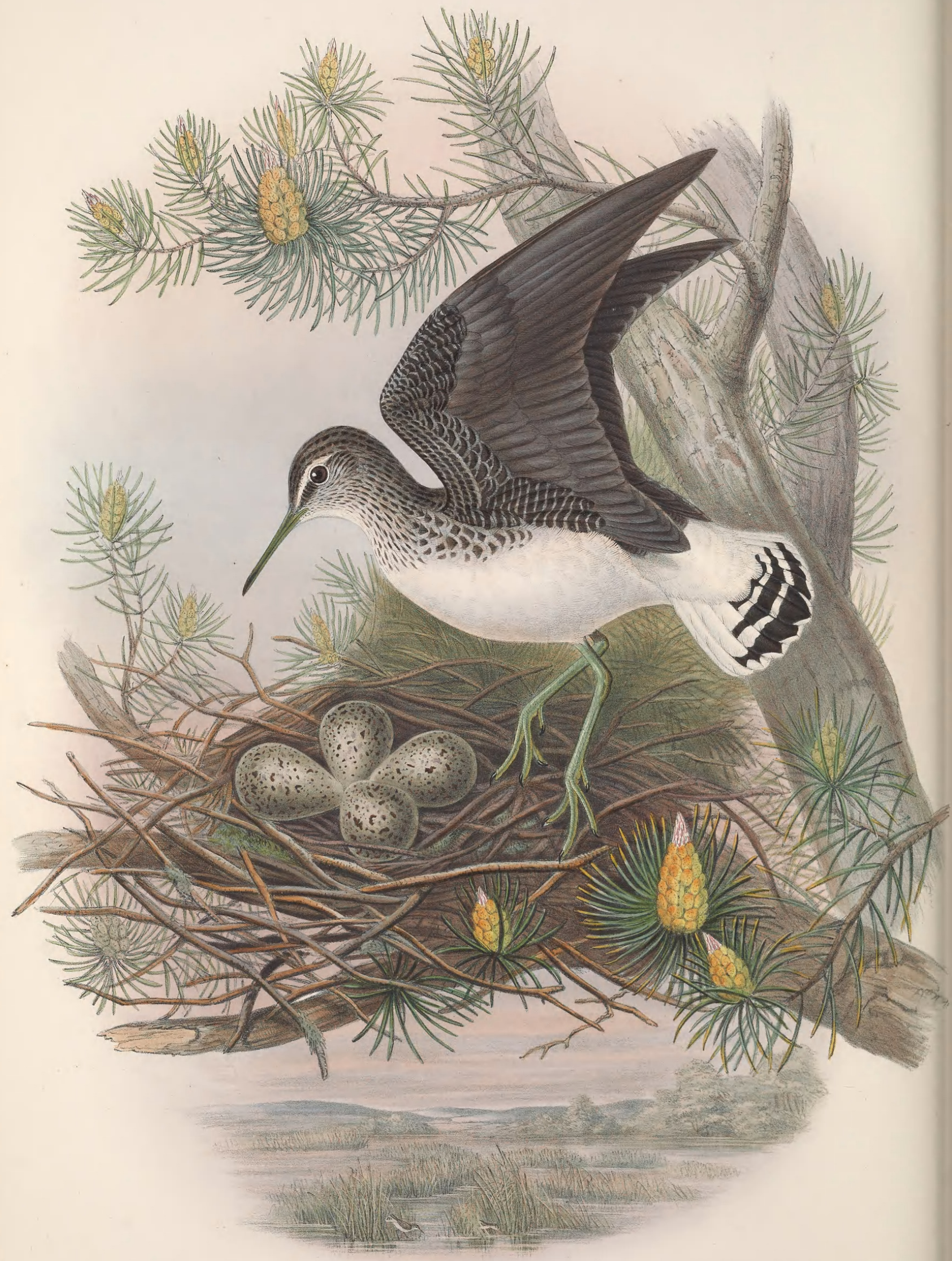




\title{
TOTANUS OCHROPUS.
}

\author{
Green Sandpiper.
}

\author{
Tringa ochropus, Linn. Syst. Nat., tom. i. p. 250. \\ Aldrovandi, Ray, Syn., p. 108, A 7, 8 . \\ glareola, Markw. in Trans. Linn. Soc., vol. i. p. 128, and vol. ii. p. 325. \\ Totanus ochropus, Temm. Man. d'Orn., p. 420. \\ , rivalis, et leucourus, Brehm, Handb. Naturg. aller Vög. Deutschl., pp. 641, 642, 643. \\ Helodromos ochropus, Bonap. Compt. Rend. de l'Acad. des Sci., tom. 43, séances des 15 et 22 Sept. 1856. \\ Helodromas ochropus, A. Newton, in Proc. Zool. Soc. 1863, p. 529.
}

Those persons who are in the habit of wandering over meads and grassy lands, with their little round ponds for the watering of cattle, or by the sides of brooks, rivulets, and reservoirs, must have frequently risen a bird about the size of a Snipe, conspicuous for its strong and rapid flight, and for the loud whistling cry it emits as it mounts in the air. This is the Green Sandpiper-a bird which frequents the smallest water-holes as well as the margins of streams. In such situations this elegantly formed bird trips lightly over the oozy mud or along the edge of the water in search of insects and their larvæ. Although it is sometimes seen both in winter and summer, it is most frequently met with during its spring and autumnal migrations; at other periods it is either breeding in countries further north, or wintering in more southern latitudes. That it never stays and breeds with us is almost certain, notwithstanding the assertion of some ornithologists to the contrary. Wide-spread, indeed, is it in the countries of the Old World, since it is very generally distributed over the whole of Europe, Africa, India, China, and Japan. I have received specimens from Borneo; and it doubtless visits the neighbouring islands of Sumatra and Java, as it certainly does St. Helena in the South Atlantic.

That exceptions to general rules exist in the habits of birds as well as in all other animals, is shown in many instances; but, I presume, it never entered the brain of the most imaginative ornithologist that a Sandpiper laid its eggs high up in a tree, until the fact was made known by the foresters and savans of Scandinavia and Pomerania; and if positive and authentic evidence of the truth of their statements had not been produced, such an assertion would not have been believed. It is only as yesterday that its anomalous habit of depositing its eggs on the branches of trees has become known. The Peewit resorts for the purpose of nidification to open commons and waste lands, the Ruff, the Redshank and the WoodSandpiper to the marsh, the Summer Snipe to the sedgy banks of streams, and the Dunlin to the upland moors; the Green Sandpiper, on the other hand, searches for the deserted nest of a Pigeon, a Jay, a Thrush, or the drey of a Squirrel, in which to deposit its very beautiful eggs. This fact may take some of my readers by surprise; but all I have said is confirmed in a paper on the subject, read by Mr. Alfred Newton at the meeting of the Zoological Society of London held on the 8th of December 1863, of which the following are the more important passages :-

“In the 'Journal für Ornithologie' for 1855, Herr Wiese, writing on the Ornithology of Pomerania, especially in the district of Cöslin, says that he had first heard from an old sportsman, who knew the peculiarities of all the forest-animals, that the Totanus ochropus nested in old Thrushes' nests, which information, he remarks, 'I naturally did not believe;' but he states that some years after, in 1845, he obtained from the same man four fine eggs of a bird of this species, which for many years had been wont to nestle in an old beech tree. Still doubtful on the subject, the following spring he himself found a nest of the bird on a pine which had a fork about five-and-twenty or thirty feet high. 'Joyfully,' he says, 'I climbed the tree, and found in that fork four eggs on a simple bed of old moss.' In the spring of 1853 he again obtained four eggs of the same species; and on the 25th of May 1854 he found four others placed in the old nest of a Song-Thrush, out of which the shed buds of the beech had not so much as been removed.

“In the 'Naumannia' for 1856, in an account of an excursion in Western Pomerania, Dr. Altum states that Totanus ochropus returns annually to its old nesting-places, these being Misseltoe-Thrushes' nests, whose remains were still to be seen, often some hundred yards distant from the nearest pool, and their height fifteen feet or more from the ground. The same journal for 1857 contains a valuable series of observations on the birds of the same district by Herr W. Hintz, in which the author says that on the 6th of May, 1855 , he found three eggs of this bird on an 'Else' [quære, Pyrus domestica ?] in an old Dove's nest, as he thinks, though he states it might have been that of a Jay. Formerly, he proceeds to remark, he had only observed this Sandpiper to use old nests of Turdus musicus, excepting once, when he found some young ones, only a few days old, hard by a river-bank on a layer of pine-needles on an 'Else'-stub. 
"I have now to read to you a portion of a letter, dated November 27, 1861, which I received from my friend Pastor Theobald, of Copenhagen. He says as follows :-

" "The nidification of Totanus ochropus is so remarkable that I do not fear to trouble you with the history the Forester Hintz has given me. He writes:- "This year I succeeded in finding the nest of Totanus ochropus. On the 9 th of May I took four eggs of this bird; they were found in an old nest of Turdus musicus, and seemed to have been incubated about three days. The very same day there were brought to me four other eggs of this bird, also found in a Thrush's nest. The 10th of May there was shown to me a nest, thirty feet high, on an old birch, the bird having chosen an old decayed nest of a Squirrel. This nest was the highest I have ever seen. Three young ones had just been hatched; in the fourth egg the bird was about to break the shell. One jumped down and concealed itself on the edge of a water-pool. The 11th of May a nest with four fresh eggs was found, but they did not come into my hands; this was in an old Pigeon's nest on a Pinus rubra, and full of dry pine-leaves. The 20th of May two eggs, almost burst by the young, were found in an old Thrush's nest, the two missing birds having most likely already left the nest. The 22nd of May four young ones, apparently but a few hours old, were found in the old nest of a Lanius collurio, in a juniper three feet high. The 24th of May four young ones were found in the hole of a Populus tremula thrown down by the wind. The year before, Muscicapa luctuosa had its nest in the trunk as it lay on the ground; this year Totanus ochropus had chosen the same opening. When I approached the trunk, the young ones, perhaps four-and-twenty hours old, jumped away and hid themselves in the grass among the branches. All these nests were near the water,two on the edge of a rivulet, the others on wet morasses, the distance from the water being at most six feet.",",

It will also be seen from Mr. Newton's paper, that this bird breeds in Sweden, as it doubtless does in Russia and all similar latitudes of the Old World. The eggs are generally four in number, of a very pointed form, and of an olivaceous stone-colour, thickly spotted all over with ochreous brown; they are about an inch and a half in length by an inch and an eighth in breadth.

The sexes are very similar both in size and colouring; and the young very soon acquire the adult livery, but continue for some time more numerously spotted than the adults. I am indebted to Mr. I. Edmund Harting for a very fine example of this bird, killed by him at Kingsbury, in Middlesex, on the 5th of November 1864, and for the following note which accompanied it :- "The Green Sandpiper is always the last to leave us; but I have hitherto considered it unusual to meet with it after September; this year, however, I have observed it frequently throughout October, and now as late as the early part of November. On the 22nd of December, 1863, several were observed along the feeder of our reservoir; but I thought this an exceptional case. In the spring, the Green Sandpiper comes to us about the 25th of April, and, after remaining until the middle or third week of May, leaves for six weeks, and appears again early in July. It seems strange that this species is not found breeding in England, considering that it spends so great a portion of the year therein."

I am also indebted to the Duke of Argyll for an opportunity of examining a very fine specimen shot by his Grace, in the spring of 1859, at Chenies, in Buckinghamshire, which, he observes, "does not seem a suitable locality for such a bird. The plumage is remarkably beautiful; the white of the lower parts, with the upper and under tail-coverts, is of the most spotless purity."

In further confirmation of the above statement respecting the breeding-habit of the Green Sandpiper, I may quote the following passage by Mr. Wheelwright from 'The Field' of March 22, 1862 :- "In no one work on natural history, British or foreign, have I ever seen it noticed that this bird lays its eggs in an old deserted nest, every one stating that the nest of this species is either in sand, or on a bank, or among the grass by the side of a stream. Yet in Sweden, where the bird is comparatively common, so much so that I generally procure five or six sets of eggs every year, I have never by any chance found them anywhere else than in an old nest in a fir tree."

Although from the above evidence there is no reason to doubt the fact of this species laying its eggs in the old nests of other birds, squirrels' dreys, \&c., and in bunches of moss on the branches of trees, it is probable that it also sometimes incubates on the ground, like the other members of its family.

The Plate represents the Green Sandpiper, of the size of life, with its four eggs in a nest which may have been a pigeon's, on a branch of the common Pine. 


\section{$2 \mathrm{BHL}$ Biodiversity Heritage Library}

Gould, John. 1873. "Green Sandpiper, Totanus ochropus [PI. 56]." The birds of Great Britain 4, -. https://doi.org/10.5962/p.324013.

View This Item Online: https://www.biodiversitylibrary.org/item/221609

DOI: https://doi.org/10.5962/p.324013

Permalink: https://www.biodiversitylibrary.org/partpdf/324013

\section{Holding Institution}

Smithsonian Libraries

\section{Sponsored by}

Biodiversity Heritage Library

\section{Copyright \& Reuse}

Copyright Status: Public domain. The BHL considers that this work is no longer under copyright protection.

This document was created from content at the Biodiversity Heritage Library, the world's largest open access digital library for biodiversity literature and archives. Visit BHL at https://www.biodiversitylibrary.org. 